\title{
INVESTIGATION of COLOR REMOVAL in REAL TEXTILE INDUSTRY WASTEWATER with MEMBRANE BIOREACTOR-ACTIVE CARBON SYSTEM
}

\author{
Meryem Yılmaz ${ }^{1}$, Nurtaç Öz², Ahmet Çelebi \\ Sakarya University, Engineering Faculty, Environmental Engineering Department, Esentepe Campus, \\ 54050 Serdivan, Sakarya - TURKEY, \\ ${ }^{1}$ meryem.yilmaz7@ogr.sakarya.edu.tr, orcid.org/0000-0002-8068-6633 \\ 2 Prof.Dr., nuroz@sakarya.edu.tr, orcid.org/0000-0003-2204-6993 \\ ${ }^{3}$ Assoc.Prof.Dr., ahmetc@sakarya.edu.tr, orcid.org/0000-0002-3508-2590
}

DOI: $10.32347 / 2524-0021.2021 .37 .18-21$

\begin{abstract}
The textile industry is an industry that consumes large amounts of water during production, contains various chemicals in its wastewater, conventional treatment methods are insufficient to reduce the wastewater pollution level, and has colloidal substances and color problems. Membrane bioreactor systems provide high efficiency in the treatment of textile wastewater and dyestuff removal. Removal of dyestuffs and turbidity in real textile wastewater by using a laboratory-scale membrane bioreactor system was studied. Chemical precipitation was not applied before the biological treatment for the removal of color and other pollutant parameters. A hollow fiber microfiltration membrane module was used in the system. Then a combination with an active carbon filter was created to take the color removal to a higher level. The development of the microorganism composition adapted to the textile industry was observed in the biological reactor. The system was operated with an endless sludge age and a hydraulic retention time of 24 hours. Color measurement transparency index parameter DFZ (DurchsichtsFarbZahl) was measured in a spectrophotometer at wavelengths of 436, 525, and $620 \mathrm{~nm}$ (nanometers) according to EN ISO 7887 standards. In the microfiltration permeate water, the color removal were found in $436 \mathrm{~nm}: 91-95 \%, 525 \mathrm{~nm}: 94-98 \%, 620 \mathrm{~nm}: 96-99 \%$, and in activated carbon permeate water, the color removal in $436 \mathrm{~nm}$ : $96-99 \%$ at $525 \mathrm{~nm}$ : $95-99 \%, 620 \mathrm{~nm}$ : 96-99\%, respectively. Due to the physical separation of the membrane, which is the simplest definition, high efficiencies in color removal have been achieved in the system. The activated carbon system combined with the membrane was found higher efficiency in color removal than the microfiltration output.
\end{abstract}

Key words: membrane bioreactor, textile wastewater, activated carbon, decolorization efficiency.

\section{INTRODUCTION}

The rapid increase in industrial establishments, which play an active role in every aspect of our lives, and the increase in population, has gradually reduced the access to consumable water resources over the years. Industries that consume high amounts of water should treat the wastewater generated during industrial and commercial activities and be suitable for reuse by bringing them to appropriate standards in their processes [1].

Since conventional methods in wastewater treatment do not reduce the pollution level of wastewater to the desired level, advanced treatment methods should be applied. Based on the difference of industrial processes in untreated wastewater and when it is necessary to evaluate these pollution degrees with an average percentage, the content of the wastewater; consists of $99 \%$ organic and inorganic substances and $1 \%$ other substances [2].

The parameters that determine the pollutant characterization of untreated wastewater are total nitrogen, total phosphorus, suspended solids, chemical oxygen demand, and biological oxygen demand. In addition, coliform bacteria are an essential living group that threatens to receive environments and surface waters [6]. 
Membrane Bioreactors (MBR) are formed by using immersion-type membranes in the biological reactor or external membranes installed separately from the biological treatment system [7]. These systems are environmentally friendly, and while performing biological purification with the help of microorganisms, they will also help treat wastewater bypassing the biologically treated water through the membrane. Thanks to the pressure applied to the membrane, solid-liquid separation takes place, and as a result of this separation, the final settling pool will not be needed [8]. Membrane technologies; It is a treatment technology that provides advantages over other technologies, with less space requirement, efficient operation at high biomass concentration, and high treatment efficiency to ensure water recovery.

Activated carbon systems make Physicochemical treatment, and the adsorption mechanism operates during the purification of water. Application areas of activated carbon are removing organic matter, color, odor, taste, and chlorine in the water. When necessary, it has the feature of forming a biofilm when organic matter is passed over the surface of activated carbon.

The textile industry causes high amounts of wastewater, especially in washing processes. According to the diversity of organic and inorganic substances in the chemicals used for dyeing and printing processes, the characterizations of the wastewaters are different. Unless a robust treatment technology is applied, it will cause a high concentration of pollutants in the receiving environment [3].

Giving colored waters from dyeing to the receiving environment will slow down the photosynthetic activities at the discharge point and reduce the oxygenation in the aquatic environment. Living organisms from microorganisms to macroorganisms will be adversely affected, and the ecological balance will be disturbed [4].

During the textile industry washing processes, $50 \%$ of the dyestuff is mixed with the wastewater without adhering to the fabric surface [5].

In the studies, the treatment of textile industry wastewater containing dyestuffs with membrane technologies has provided high efficiency in the effluent and made it possible to recover water in industries. Our study aims to remove real, dyed wastewater generated in situ with the MBR system [6].

\section{MATERIAL METHOD}

\section{Experimental Study}

A laboratory-scale aerobic membrane bioreactor system was used in the studies, and this reactor system was made of aquarium glass.

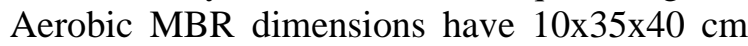
and $0.6 \mathrm{~mm}$ glass thickness and work with $1 \mathrm{~L}$ wastewater for $11 \mathrm{~L}$ volume in total $13 \mathrm{~L}$ (Biomass + wastewater).

The membrane frame module $(33 \times 33 \mathrm{~cm})$ used in the aerobic MBR system is a single outlet, hollow fiber microfiltration-ultrafiltration membrane. The nominal pore diameter of the membrane, which works with the PVDF outsideto-in flow principle with a hydrophilic surface feature, is 0.04 microns. Eighty-four hollow fiber membranes are placed vertically on the frame module membrane, and each has a surface area of $0.0015 \mathrm{~m} 2$. The maximum operating temperature of the membrane is $40^{\circ} \mathrm{C}$, and it has been worked at $25{ }^{\circ} \mathrm{C}$ room temperature. The operational $\mathrm{pH}$ range of the membrane is between 5 and 9.5, and the $\mathrm{pH}$ range in this study is between 6-9.

In the bioreactor, a certain level of air must be given for the living microorganisms to survive and not clog the membrane surface. The air is supplied by diffusers $(35 \mathrm{~cm}$ aquarium air stone) connected to the air motors. In the system, there is a peristaltic pump with a flow rate of $0.0002 \mathrm{ml} / \mathrm{min}-380 \mathrm{ml} / \mathrm{min}$ to vacuum the permeate water in the membrane.

An active carbon filter operating at a temperature of 4-45 0C and a $\mathrm{pH}$ range of 6.59.5 was used to improve color removal.

\section{Inoculation and Color}

The microorganism culture was taken from the recycling sludge of a biological wastewater treatment plant in Sakarya. Since textile industry wastewater is highly toxic wastewater, it is estimated that introducing microorganisms into a bioreactor with a complex structure will cause adaptation problems in living things. To minimize this situation, a nutrient solution mixed with textile wastewater containing carbon, nitrogen, and phosphorus elements was given to the reactor until the adaptation of microorganisms was achieved.

The color was measured at 436, 520, and 625 $\mathrm{nm}$ wavelengths with the DFZ (DurchsichtsFarbZahl) method called the 'Transparency Index.' 
RESULT and DISCUSSION

As a result of color measurement of raw textile wastewater, 77.4 for Color 436, 65.7 for
Color525, and 60.3 for Color620 were found. Daily measurement results are shown in the graphs below.
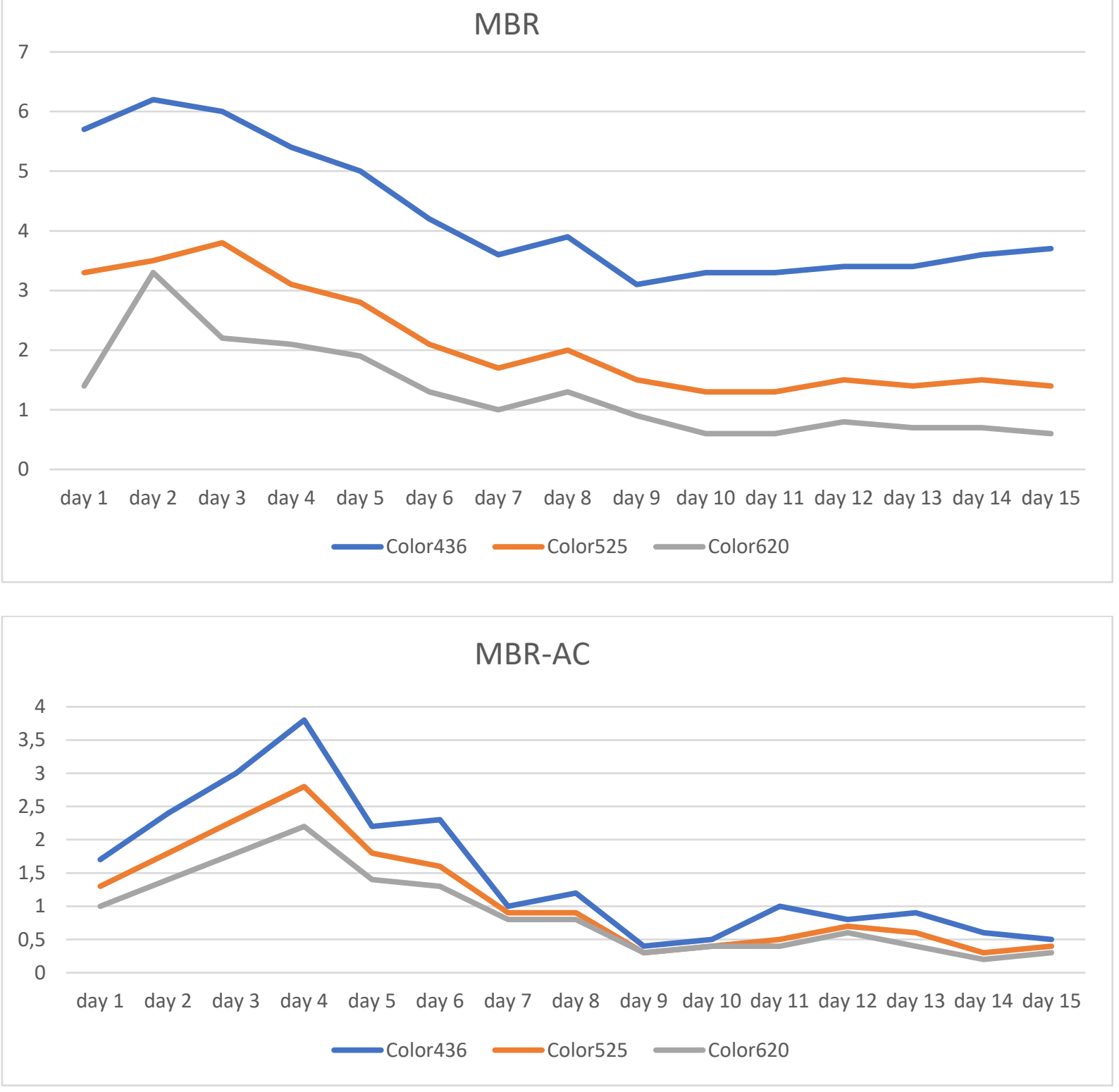

\section{CONCLUSION}

This study was investigated high-efficiency color removal with microorganisms adapted against toxicity in the membrane bioreactor system of real textile industry wastewaters. After the membrane bioreactor system, the color removal with the activated carbon filters installed in the system had positive effects in terms of appearance and removal. Before the biological treatment in the system, no chemical pretreatment was applied, and it was worked with environmentally friendly technology. The reactor was operated with a hydraulic waiting period of 24 hours and an endless sludge age without sludge from the system. Working in the eternal sludge age has ensured that the sludge is kept in the reactor, and the sludge load to be disposed of is reduced. Chemical pretreatment and not adding chemicals to strengthen flocculation reduced the sludge load from other treatment units. It has been found that the use of membrane bioreactors together with the activated carbon system is a critical component that improves wastewater quality. 


\section{ACKNOWLEDGEMENTS}

This work was supported by Sakarya University Scientific Research Projects Coordinatorship. (Project Number: 2019-7-24-119)

\section{REFERENCES}

1. Khouni, I., Louhichi, G., \& Ghrabi, A. (2020). Assessing the performances of an aerobic membrane bioreactor for textile wastewater treatment: Influence of dye mass loading rate and biomass concentration", Process Safety and Environmental Protection, 135 , 364-382.

https://doi.org/10.1016/j.psep.2020.01.011

2. Üstün Odabaşı, S., Altın, S. H., \& Büyükgüngör H. (2020). Occurence, Fate And Removal Of Micropollutants From Aquatic Environment With Advanced Oxidation Processes, NOHU J. Eng. Sci., 9(1), 57-71 https://doi.org/10.28948/ngumuh.526064
3. Kocaer, F. O., \& Alkan, U. (2002). Treatment alternatives for textile effluents containing dyes. J Uludag Univ Eng Archit Faculty, 7(1), 47-55.

4. Correia, V. M., Stephenson, T., \& Judd, S. J. (1994). Characterisation of textile wastewaters - a review. Environmental Technology, $\quad$ 15(10), $\quad 917-929$ https://doi.org/10.1080/09593339409385500

5. Uysal, Y., \& Bilgiç, M. (2017). Color Removal from Wastewater by Using Two-Step (Biological and Chemical) Aerobic Filter Reactors Environmental Sciences, 20(1), 7-13. https://doi.org/10.30955/gnj.002255

6. Cevretek (2017). MBR - Environmental Technologies. Retrieved from https://cevretek.com.tr/membran-bio-reaktor/

\title{
Дослідження знебарвлення стічних вод текстильної промисловості комбінованою системою мембранний біореактор-активоване вугілля
}

\author{
Meryem Yllmaz, Nurtaç Öz, Ahmet Çelebi
}

Анотація. Текстильна промисловість - це галузь, яка під час виробництва споживає велику кількість води, містить різні хімічні речовини в стічних водах, звичайних методів очищення недостатньо для зниження рівня забруднення стічних вод, має колоїдні речовини та проблеми 3 кольором. Мембранні біореакторні системи забезпечують високу ефективність очищення текстильних стічних вод і видалення барвників.

Досліджено видалення барвників та каламутності в реальних текстильних стічних водах за допомогою лабораторного мембранного біореактору. До біологічної обробки для видалення кольору та інших забруднювачів хімічне осадження не застосовувалося. В системі використовувався поруватий мембранний модуль мікрофільтрації. Також була досліджена комбінована технологія з фільтром з активованим вугіллям, для інтенсифікації знебарвлення. У біологічному реакторі спостерігали розвиток адаптованого до текстильної промисловості складу мікроорганізмів. Система працювала 3 необмеженим віком мулу та гідравлічним часом утримання 24 години. Параметр індексу прозорості кольорових вимірювань DFZ (Durchsichts Farb Zahl) вимірювали на спектрофотометрі на довжинах хвиль 436, 525 та 620 нм відповідно до стандартів EN ISO 7887. У воді після мікрофільтрації було виявлено наступні ефекти знебарвлення: для 436 нм - 91-95\%; 525 нм - 94-98\%; 620 нм - 96-99\%, а в пермеаті після обробки активованим вугіллям: 436 нм 96-99\%; 525 нм - 95-99\%; 620 нм - 96-99\%, відповідно. Завдяки фізичному поділу мембрани, що є найпростішим рішенням, у системі було досягнуто високої ефективності видалення кольору. Система активованого вугілля в поєднанні з мембраною виявила більш високу ефективність видалення кольору, ніж мікрофільтрація.

Ключові слова: мембранний біореактор, текстильні стічні води, активоване вугілля, ефективність знебарвлення. 